\title{
Investigation of Factors Affecting the Number of Automobiles Owned by Households: Count Data Model
}

\author{
Kübranur Çebi Karaaslan1 1 (ㅇ
}

\begin{abstract}
The automobile industry is a service-oriented industry that is constantly developing. Households are the most important interlocutors in this industry. The study's aim in this direction is to determine what factors influence the number of automobiles owned by households. The factors that affect this number, as well as the extent of these affects, have been investigated in the study. The study's data set was obtained from the Turkish Statistical Institute's Household Budget Surveys. Count data models were used in the study. As a result of the study, the gender, age, educational status, marital status, working status of the household head, household size, annual available income, second house ownership, saving status, eating out habits, going to the movie habits, going to the market habits, difficulty in accessing public transportation services, difficulty in accessing compulsory education services and the variables of the survey year were statistically significant. The information presented in this study is expected to help decision makers and policymakers who benefit from the automobile sector, particularly automobile industry manufacturers.
\end{abstract}

Keywords

Number of Automobile, Automobile Ownership, Poisson Regression, Count Data Models

\section{Introduction}

The automobile industry is a highly competitive industry that is constantly changing and developing. The automotive industry has a sizable and effective market share that benefits all segments of society. The automobile industry is a major economic driver in developing countries such as Turkey. A developed automobile industry is a feature shared by all industrialized countries (Karaatlı et al., 2012: 88). There are many brands in the industry that offer various options for a wide range of budgets, suitable for individuals' needs or luxury expectations. The desire of individuals to live more independently and to avoid public transportation as much as possible, particularly in the recent Covid-19 pandemic, has made automobile ownership important, despite the fact that excessive tax burdens on automobiles in Turkey force individuals hands in terms of automobile ownership, which is no longer a luxury and has become a necessity. 
Since 2015, Turkey's automobile ownership has increased. Although an increase in the number of automobiles is a sign of prosperity, it also has certain negative consequences. It contributes to traffic congestion, particularly in congested cities, as well as the spread of emissions into the atmosphere. Road transport contributes significantly to pollution. As a result of global warming, the amount of emissions in the atmosphere increases as the number of vehicles increases, causing ozone layer damage and negative effects on the lives of many (Otken and Gümüşay, 2009: 1).

The study's purpose is to determine what factors influence the number of automobiles in a population. Nowadays, the number of employed people in a family is more than one, and the regular daily flow of life is gradually accelerating, so an automobile frequently far from meets the needs of the household. Especially in Turkey, due to the currency fluctuations and the everincreasing tax burdens, automobile ownership has begun to be seen as an investment as well as a necessity and this study was motivated by this situation. The study's findings may be useful to decision makers and policymakers who benefit from the automobile industry, particularly automobile manufacturers, by providing information on the factors influencing the number of automobiles owned by households, which are important interlocutors of the automobile sector.

This work consists mainly of five parts. Following the introduction, the second section contains a literature review. The third section describes the data set, variables, and econometric method used in the study. The results of the analysis are presented in the fourth part, and the results are discussed and evaluated in the final part.

\section{Literature Review}

Other economic factors, particularly gender, marital status, educational status, and income, were found to have an effect on automobile ownership in studies conducted as seen in the literature review. Some of the studies on this subject are identified below.

Scott and Axhausen (2006) conducted research on the mobility needs of households. The study's data set was obtained through a survey conducted in Germany. In the study, the bivariate-ordered probit regression model was used. According to the findings of the study, income is important for both season tickets and automobiles, but as income rises, so does the preference for automobiles over seasonal tickets, and the further a household lives from the city centre, the more likely it is to own one or more automobiles.

Potoglou and Kanaroglou (2008) investigated the influence of socioeconomic factors on the number of automobiles owned by a household. A questionnaire was used in the study, as well as a multinominal logistic regression model. The study discovered that the number of working adults and persons with a driver's license affects the number of automobiles, that an 
increase in the number of employees increases the likelihood of the household having two or more automobiles, and that households with children and married children are more likely to have two automobiles than single individuals.

Li et al. (2010) investigated the influence of socioeconomic and demographic factors on private vehicle ownership in China's megacities. The study relied on questionnaire data and employed discrete choice models. According to the findings of the study, urban welfare, urban scale, and road infrastructure all have significant positive effects on private vehicle ownership in cities.

In their study, Ritter, and Vance (2013) investigated the effect of reduced family size on the number of automobiles. The study's data set was taken from German household data. In the study, the multinominal logistic regression method was used. The study showed that, despite Germany's declining population, there will be an increase in automobile ownership until 2030, that the projected increase in automobile ownership is related to an increase in household income, and that distance from public transportation is an important determinant of vehicle ownership.

Guo investigated the effect of parking spaces in residences on automobile ownership (2013). The study's data set was obtained via a survey application in New York. According to the findings of the study, garage, driveway, and street parking all have a positive effect on automobile ownership.

Gómez-Gélvez and Obando investigated the determinants of household automobile ownership (2013). The study's data set was obtained through a survey conducted in Colombia. The data in the study was analysed using discrete choice models. According to the findings of the study, income has a major effect on vehicle ownership, and the distance to work influences automobile ownership.

In their study, Akay and Tümsel (2015) studied the factors affecting automobile ownership. In the study, the sequential logistic regression method was used. The study included data from 3733 households from the 2013 Budget Survey. As a result of the study, it was determined that the variable that most negatively affects automobile ownership is a household's monthly expenditures, and the variable that most positively affects the probability of a household owning an automobile is income.

Oakil et al. (2016) examined the factors affecting young people's automobile ownership. The study employed logistic regression analysis. The study results showed a decrease in automobile ownership among young people in the Netherlands. The effect of urbanization level on automobile ownership was found to be much stronger for young couples than for young families or singles. 
Another study conducted by Çınar (2018) examined the effect of socioeconomic and demographic factors on consumer automobile ownership. The study's data set was gathered by administering a questionnaire to 2000 people working in Bursa. In the study, a logistic regression model was used. According to the findings of the study, home ownership is the most influential factor on automobile ownership, followed by gender and marital status.

Gürel studied the factors affecting automobile ownership (2019). The study's data set was gathered using a questionnaire administered in Denizli. In the study, binary logistic regression analysis was used. The monthly total income of the household, the number of people with a driver's license in the household, the educational status of the household head, the age of the household head, the number of people with a public transportation card in the household, and the household ownership status were found to be significant factors according to the results of the study.

Memişoğlu and Can (2021) studied the factors affecting purchase decisions in the luxury automotive sector. The study's data set was based on survey data collected in 2019. According to the findings of the study, status, uniqueness, safety, comfort, and environmental sensitivity are important factors in people's luxury automobile preferences.

\section{Methodology}

\section{Data Set}

The purpose of this study was to investigate the factors affecting the number of automobiles owned by households in Turkey. In the study, the Household Budget Survey of the Turkish Statistical Institute for the years 2015-2019 was used. The stratified two-stage cluster sampling method was used to obtain the data in the Household Budget Survey (Turkish Statistical Institute, [TUIK], 2021). Finally, the study included data on 59102 household heads.

\section{Variables}

The study examined the demographic, economic, social, and environmental structures of households in order to conduct an econometric analysis of the number of automobiles owned by households. In practice, the number of automobiles to be used as a dependent variable covers the modes of transportation used by households for special purposes other than commercial purposes.

The factors in the study's data set and the factor affecting household automobile ownership were identified as independent variables. The independent variables were gender, age, educational status, marital status, working status of the household head, household size, annual available income, second housing ownership, saving status, eating out habits, going to the movie habits, going to the market habits, difficulty in accessing public transportation ser- 
vices, difficulty in accessing compulsory education services, and year factors. Furthermore, the age variable was classified to examine the effects in different life stages, and the income variable was classified to examine the effects in different income levels.

\section{Research Method}

The study employed poisson regression analysis, which was carried out using the Stata 14.1 program. Initially, descriptive statistics for independent variables were used, followed by poisson regression analysis to look at the factors influencing the number of automobiles owned by households.

\section{Results}

\section{Descriptive Statistics}

Table 1 contains the category definitions and descriptive statistics for the variables in the study. The average number of automobiles per household was 0.453 , with a household size of 3.473 . It was determined that $83.9 \%$ of household heads were male, $23.3 \%$ were between the ages of 45 and 54 , the majority $(81.8 \%)$ were married couples living together, $25.7 \%$ had a university degree, and $65.4 \%$ were working in some capacity. Furthermore, $8.4 \%$ owned second homes, the majority $(69.8 \%$ ) did not save money, $36.6 \%$ dined out frequently, $7.4 \%$ went to the movies frequently, $62.8 \%$ went to the market frequently, $65.8 \%$ had easy access to public transportation, $63.4 \%$ had easy access to health care, and $69.1 \%$ had easy access to compulsory education.

Table 1

Descriptive Statistics of Variables

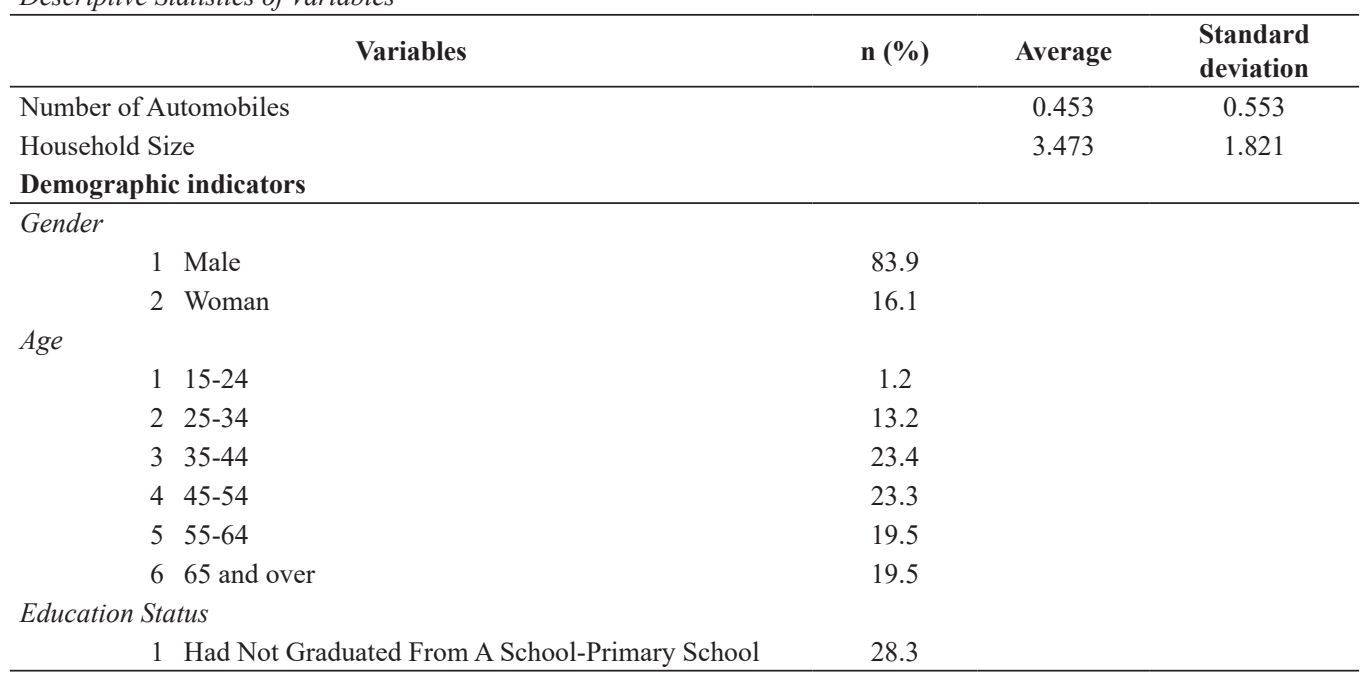




\begin{tabular}{|c|c|}
\hline Variables & n (\%) \\
\hline 2 Secondary school & 31.7 \\
\hline 3 High school & 14.3 \\
\hline 4 University & 25.7 \\
\hline \multicolumn{2}{|l|}{ Marital status } \\
\hline 1 Never Married & 3.9 \\
\hline 2 Married & 81.8 \\
\hline 3 Divorced - Spouse Dead & 14.3 \\
\hline \multicolumn{2}{|l|}{ Economic indicators } \\
\hline \multicolumn{2}{|l|}{ Working Status } \\
\hline 1 Working & 65.4 \\
\hline 2 Not Working & 34.6 \\
\hline \multicolumn{2}{|l|}{ Income Level } \\
\hline 1 1st Income Level (lowest) & 25.0 \\
\hline 2 2nd Income Level & 25.0 \\
\hline 3 3rd Income Level & 25.0 \\
\hline 44 th Income Level (highest) & 25.0 \\
\hline \multicolumn{2}{|l|}{ Second Home Ownership } \\
\hline 1 Yes & 8.4 \\
\hline $2 \mathrm{No}$ & 91.6 \\
\hline \multicolumn{2}{|l|}{ Saving Status } \\
\hline 1 Yes & 30.3 \\
\hline $2 \mathrm{No}$ & 69.8 \\
\hline Social and environmental indicators & \\
\hline
\end{tabular}

Eating Out Habits

1 Yes 36.6

2 No $\quad 63.4$

Going to the Movies Habits
1 Yes
7.4
$2 \mathrm{No}$
92.6

Going to the Market Habits

1 Yes $\quad 62.8$

2 No $\quad 37.2$

Difficulty Accessing Public Transport Services

$\begin{array}{lll}1 & \text { Easy } & 65.8 \\ 2 & \text { Middle } & 11.1 \\ 3 & \text { Hard } & 23.1\end{array}$

Difficulty Accessing Health Services

1 Easy $\quad 63.4$

2 Middle 11.9

3 Hard 24.7

Difficulty Accessing Compulsory Education Services
1 Easy
69.1
2 Middle
10.8
3 Hard
20.0 


\section{Model Estimation}

The study used count data models to determine the number of automobiles owned by households. Because the dependent variable included the observation " 0 ," the zero-inflated poisson regression model and the poisson regression model were statistically compared, and the resulting test statistic indicated that the poisson regression model should be used. (Vuong test of zip vs. standard Poisson: $\mathrm{z}=-2.04 \mathrm{Pr}>\mathrm{z}=0.9793)$. The established poisson regression model was found to be statistically significant $(\mathrm{P}<0.000)$. The poisson regression model renders the important assumption that there is equal dispersion. Equal dispersion occurs when the variance equals the average, whereas overdispersion occurs when the variance exceeds the average. To determine whether the overdispersion parameter was statistically significant, the likelihood ratio (LR) and Wald tests were used (Dinarcan, 2018: 11; Üçdoğruk and Şengül, 2021: 191). An LR test was used in the study to test for overdispersion. The LR test revealed that the $\alpha$ coefficient was statistically insignificant and that there was no overdispersion. According to this result, it was discovered that poisson regression to the data set was appropriate, and it was studied with robust standard errors.

The presence of multicollinearity between the independent variables that were to be included in the Poisson regression model were tested. The variance inflation factors (Vif) for the independent variables are shown in Table 2.

Table 2

Variance Inflation Factors

\begin{tabular}{|c|c|}
\hline Variables & Vif \\
\hline \multicolumn{2}{|l|}{ Demographic indicators } \\
\hline \multicolumn{2}{|l|}{ Gender (reference: male) } \\
\hline Female & 2.09 \\
\hline \multicolumn{2}{|l|}{ Age (reference: 65 and over) } \\
\hline $15-24$ & 1.25 \\
\hline $25-34$ & 2.27 \\
\hline $35-44$ & 2.78 \\
\hline $45-54$ & 2.36 \\
\hline $55-64$ & 1.79 \\
\hline \multicolumn{2}{|c|}{ Education Status (reference: had graduated from a school-primary school) } \\
\hline Secondary School & 1.90 \\
\hline High School & 1.60 \\
\hline University & 2.42 \\
\hline \multicolumn{2}{|c|}{ Marital Status (reference: married) } \\
\hline Never Married & 1.29 \\
\hline Divorced - Spouse Dead & 2.16 \\
\hline Household Size & 1.42 \\
\hline \multicolumn{2}{|l|}{ Economic indicators } \\
\hline \multicolumn{2}{|c|}{ Working Status (reference: not working) } \\
\hline Working & 1.65 \\
\hline \multicolumn{2}{|c|}{ Income Level (reference: 1 st income level (lowest)) } \\
\hline 2nd Income Level & 1.65 \\
\hline
\end{tabular}




\begin{tabular}{lc}
\hline Variables & Vif \\
\hline Economic indicators & 1.88 \\
\hline 3rd Income Level & 2.44 \\
4th Income Level (highest) & 1.06 \\
$\begin{array}{l}\text { Second Home Ownership (reference: } n o \text { ) } \\
\quad \text { Yes }\end{array}$ & \\
Saving Status (reference: no) & 1.20 \\
$\quad$ Yes & \\
Social and environmental indicators & 1.31 \\
\hline Eating Out Habits (reference: no) & 1.15 \\
$\quad$ Yes & \\
Going to the Movies Habits (reference: no) & 1.08 \\
$\quad$ Yes & \\
Going to the Market Habits (reference: no) & 1.93 \\
$\quad$ Yes & 3.00 \\
Difficulty Accessing Public Transport Services (reference: easy) & \\
$\quad$ Middle & 2.25 \\
$\quad$ Hard & 3.54 \\
Difficulty Accessing Health Services (reference: easy) & \\
$\quad$ Middle & 2.02 \\
$\quad$ Hard & 2.78 \\
Difficulty Accessing Compulsory Education Services (reference: easy) & 1.34 \\
$\quad$ Middle & 1.91 \\
$\quad$ Hard & \\
Year &
\end{tabular}

The presence of a high-grade multicollinearity is indicated by a variance inflation factor greater than 10, whereas the absence of a multicollinearity is indicated by a variance inflation factor less than 5 (Alkan et al., 2015: 28). In the study, there was no multicollinearity between the arguments. The Poisson regression model's results are shown in Table 3.

Table 3

Poisson Regression Model Estimation Results

\begin{tabular}{|c|c|c|c|c|c|}
\hline \multirow{2}{*}{ Variables } & \multirow{2}{*}{$\boldsymbol{\beta}$} & \multirow{2}{*}{$\begin{array}{l}\text { Robust Std. } \\
\text { Error }\end{array}$} & \multirow{2}{*}{$\mathbf{P}$} & \multicolumn{2}{|c|}{ 95\% Conf. Interval } \\
\hline & & & & $\mathbf{L L}$ & UL \\
\hline \multicolumn{6}{|l|}{ Demographic indicators } \\
\hline \multicolumn{6}{|l|}{ Gender (reference: male) } \\
\hline Female & -0.342 & 0.026 & 0.000 & -0.392 & -0.291 \\
\hline \multicolumn{6}{|l|}{ Age (reference: 65 and over) } \\
\hline $15-24$ & -0.203 & 0.072 & 0.005 & -0.345 & -0.060 \\
\hline $25-34$ & 0.004 & 0.022 & 0.855 & -0.040 & 0.048 \\
\hline $35-44$ & 0.121 & 0.020 & 0.000 & 0.082 & 0.161 \\
\hline $45-54$ & 0.190 & 0.019 & 0.000 & 0.153 & 0.227 \\
\hline $55-64$ & 0.209 & 0.018 & 0.000 & 0.174 & 0.244 \\
\hline \multicolumn{6}{|c|}{ Education Status (reference: had not graduated from a school-primary school) } \\
\hline Secondary School & 0.178 & 0.015 & 0.000 & 0.149 & 0.208 \\
\hline High School & 0.187 & 0.017 & 0.000 & 0.153 & 0.220 \\
\hline
\end{tabular}




\begin{tabular}{|c|c|c|c|c|c|}
\hline \multirow{2}{*}{ Variables } & \multirow{2}{*}{$\boldsymbol{\beta}$} & \multirow{2}{*}{$\begin{array}{l}\text { Robust Std. } \\
\text { Error }\end{array}$} & \multirow{2}{*}{$\mathbf{P}$} & \multicolumn{2}{|c|}{ 95\% Conf. Interval } \\
\hline & & & & LL & UL \\
\hline \multicolumn{6}{|l|}{ Demographic indicators } \\
\hline \multicolumn{6}{|l|}{ Marital Status (reference: married) } \\
\hline Never Married & -0.477 & 0.038 & 0.000 & -0.551 & -0.403 \\
\hline Divorced - Spouse Died & -0.379 & 0.028 & 0.000 & -0.435 & -0.323 \\
\hline Household Size & 0.009 & 0.003 & 0.005 & 0.003 & 0.015 \\
\hline \multicolumn{6}{|l|}{ Economic indicators } \\
\hline \multicolumn{6}{|l|}{ Working Status (reference: not working) } \\
\hline Working & 0.072 & 0.013 & 0.000 & 0.046 & 0.097 \\
\hline \multicolumn{6}{|c|}{ Income Level (reference: 1st income level (lowest)) } \\
\hline 2nd Income Level & 0.562 & 0.022 & 0.000 & 0.519 & 0.605 \\
\hline 3rd Income Level & 0.832 & 0.022 & 0.000 & 0.790 & 0.874 \\
\hline 4th Income Level (highest) & 1.104 & 0.022 & 0.000 & 1.060 & 1.147 \\
\hline \multicolumn{6}{|l|}{ Second Home Ownership (reference: no) } \\
\hline Yes & 0.281 & 0.013 & 0.000 & 0.257 & 0.306 \\
\hline \multicolumn{6}{|l|}{ Saving Status (reference: no) } \\
\hline Yes & 0.121 & 0.010 & 0.000 & 0.102 & 0.140 \\
\hline \multicolumn{6}{|l|}{ Social and environmental indicators } \\
\hline \multicolumn{6}{|l|}{ Eating Out Habits (reference: no) } \\
\hline Yes & 0.098 & 0.010 & 0.000 & 0.078 & 0.118 \\
\hline \multicolumn{6}{|c|}{ Going to the Movies Habits (reference: no) } \\
\hline Yes & 0.046 & 0.014 & 0.001 & 0.018 & 0.074 \\
\hline \multicolumn{6}{|c|}{ Going to the Market Habits (reference: no) } \\
\hline Yes & 0.125 & 0.010 & 0.000 & 0.105 & 0.145 \\
\hline \multicolumn{6}{|c|}{ Difficulty Accessing Public Transport Services (reference: easy) } \\
\hline Middle & 0.031 & 0.020 & 0.121 & -0.008 & 0.070 \\
\hline Hard & 0.049 & 0.019 & 0.010 & 0.012 & 0.086 \\
\hline \multicolumn{6}{|c|}{ Difficulty Accessing Health Services (reference: easy) } \\
\hline Middle & 0.003 & 0.021 & 0.896 & -0.038 & 0.043 \\
\hline Hard & -0.021 & 0.021 & 0.313 & -0.062 & 0.020 \\
\hline \multicolumn{6}{|c|}{ Difficulty Accessing Compulsory Education Services (reference: easy) } \\
\hline Middle & 0.013 & 0.021 & 0.542 & -0.028 & 0.054 \\
\hline Hard & 0.081 & 0.020 & 0.000 & 0.042 & 0.120 \\
\hline Year & 0.047 & 0.004 & 0.000 & 0.040 & 0.054 \\
\hline Cons & -2.199 & 0.029 & 0.000 & -2.257 & -2.142 \\
\hline N: 59102 & & Log Likeliho & d: -4452 & .930 & \\
\hline Pseudo R²: 0.094 & & Prob: 0.000 & & & \\
\hline
\end{tabular}

When Table 3 was examined, the gender, age, educational status, marital status, working status of the household head, household size, annual available income, second housing ownership, saving status, eating out habits, going to the movie habits, going to the market habits, difficulty in accessing public transportation services, difficulty in accessing compulsory education services and the variables of the survey year were found to be statistically significant. Coefficient interpretations were to be made through marginal effects. The marginal effect values of the variables used in the model are shown in Table 4. 
Table 4

Poisson Regression Model Marginal Effect Estimation Results

\begin{tabular}{|c|c|c|c|c|c|}
\hline \multirow{2}{*}{ Variables } & \multirow{2}{*}{$\mathrm{dy} / \mathrm{dx}$} & \multirow{2}{*}{ Std. Error } & \multirow{2}{*}{$\mathbf{P}$} & \multicolumn{2}{|c|}{$95 \%$ Conf. Interval } \\
\hline & & & & $\mathbf{L L}$ & $\mathbf{U L}$ \\
\hline \multicolumn{6}{|l|}{ Demographic indicators } \\
\hline \multicolumn{6}{|l|}{ Gender (reference: male) } \\
\hline Female & -0.135 & 0.009 & 0.000 & -0.152 & -0.118 \\
\hline \multicolumn{6}{|l|}{ Age (reference: 65 and over) } \\
\hline $15-24$ & -0.073 & 0.024 & 0.002 & -0.120 & -0.026 \\
\hline $25-34$ & 0.002 & 0.009 & 0.855 & -0.016 & 0.019 \\
\hline $35-44$ & 0.052 & 0.008 & 0.000 & 0.035 & 0.068 \\
\hline $45-54$ & 0.084 & 0.008 & 0.000 & 0.068 & 0.099 \\
\hline $55-64$ & 0.093 & 0.008 & 0.000 & 0.078 & 0.108 \\
\hline \multicolumn{6}{|c|}{ Education Status (reference: had not graduated from a school-primary school) } \\
\hline Secondary School & 0.072 & 0.006 & 0.000 & 0.060 & 0.084 \\
\hline High School & 0.076 & 0.007 & 0.000 & 0.062 & 0.089 \\
\hline University & 0.160 & 0.007 & 0.000 & 0.147 & 0.173 \\
\hline \multicolumn{6}{|l|}{ Marital Status (reference: married) } \\
\hline Never Married & -0.179 & 0.011 & 0.000 & -0.201 & -0.157 \\
\hline Divorced - Spouse Died & -0.149 & 0.010 & 0.000 & -0.168 & -0.130 \\
\hline Household Size & 0.004 & 0.001 & 0.005 & 0.001 & 0.007 \\
\hline \multicolumn{6}{|l|}{ Economic indicators } \\
\hline \multicolumn{6}{|l|}{ Working Status (reference: not working) } \\
\hline Working & 0.032 & 0.006 & 0.000 & 0.021 & 0.043 \\
\hline \multicolumn{6}{|c|}{ Income Level (reference: 1st income level (lowest)) } \\
\hline 2nd Income Level & 0.160 & 0.006 & 0.000 & 0.149 & 0.172 \\
\hline 3rd Income Level & 0.276 & 0.006 & 0.000 & 0.264 & 0.288 \\
\hline 4th Income Level (highest) & 0.428 & 0.007 & 0.000 & 0.414 & 0.442 \\
\hline \multicolumn{6}{|c|}{ Second Home Ownership (reference: no) } \\
\hline Yes & 0.142 & 0.007 & 0.000 & 0.128 & 0.156 \\
\hline \multicolumn{6}{|l|}{ Saving Status (reference: no) } \\
\hline Yes & 0.055 & 0.004 & 0.000 & 0.047 & 0.064 \\
\hline \multicolumn{6}{|l|}{ Social and environmental indicators } \\
\hline \multicolumn{6}{|l|}{ Eating Out Habits (reference: no) } \\
\hline Yes & 0.045 & 0.005 & 0.000 & 0.036 & 0.054 \\
\hline \multicolumn{6}{|c|}{ Going to the Movies Habits (reference: no) } \\
\hline Yes & 0.021 & 0.007 & 0.002 & 0.008 & 0.035 \\
\hline \multicolumn{6}{|c|}{ Going to the Market Habits (reference: no) } \\
\hline Yes & 0.055 & 0.004 & 0.000 & 0.047 & 0.064 \\
\hline \multicolumn{6}{|c|}{ Difficulty Accessing Public Transport Services (reference: easy) } \\
\hline Middle & 0.014 & 0.009 & 0.125 & -0.004 & 0.032 \\
\hline Hard & 0.022 & 0.009 & 0.011 & 0.005 & 0.040 \\
\hline \multicolumn{6}{|c|}{ Difficulty Accessing Health Services (reference: easy) } \\
\hline Middle & 0.001 & 0.009 & 0.896 & -0.017 & 0.020 \\
\hline Hard & -0.009 & 0.009 & 0.311 & -0.028 & 0.009 \\
\hline \multicolumn{6}{|c|}{ Difficulty Accessing Compulsory Education Services (reference: easy) } \\
\hline Middle & 0.006 & 0.009 & 0.544 & -0.013 & 0.024 \\
\hline Hard & 0.038 & 0.009 & 0.000 & 0.019 & 0.056 \\
\hline Year & 0.021 & 0.002 & 0.000 & 0.018 & 0.025 \\
\hline
\end{tabular}


According to the marginal effects of the poisson regression model shown in Table 4, in terms of demographic indicators, female household heads had 0.135 fewer automobiles compared to men. Household heads aged 15-24 had 0.073 fewer automobiles compared to those over 65, but those aged 35-44, 45-54, 55-64 had 0.052, 0.084, 0.093 more respectively. Automobile ownership rates for secondary, high school, and college graduates were 0.072, 0.076, and 0.160 lower, respectively, compared to those who had not graduated from school/graduated from primary school. The number of households that had never married and divorced/ whose spouse had died were 0.179 and 0.149 less than those who had married, respectively. The increase in household size increased the number of automobiles owned by households by 0.004 .

In terms of economic indicators, working household heads had 0.032 more automobiles than non-working ones. Households belonging to the 2nd income level, 3rd income level and highest income level had respectively $0.160,0.276,0.428$ more automobiles than those belonging to the lowest income level. Those who had a second home had 0.142 more automobiles than those who did not. Savers had 0.055 more automobiles than those who did not.

In terms of social indicators, those who had a habit of dining-out had 0.045 more automobiles than those who did not. Those who had the habit of going to the movies had 0.021 more automobiles than those who did not. Those who had a habit of going to the market had 0.055 more automobiles than those who did not. Those who had difficult access to public transportation services had 0.022 more automobiles compared to those who had easy access. Those with difficult access to compulsory education services had 0.038 more automobiles compared to those with easy access. Over the years, the number of automobiles belonging to households increased by 0.021 .

\section{Conclusion and Discussion}

The factors affecting the number of automobiles owned by households were discussed in this study. Because the number of automobiles was the dependent variable in the count data, the poisson regression model was used as one of the count data models. As a result of the study, the gender, age, educational status, marital status, working status of the household head, household size, annual available income, second housing ownership, saving status, eating out habits, going to the movies habits, going to the market habits, difficulty in accessing public transportation services, difficulty in access to compulsory education services and survey year were found to be statistically significant. To conclude, the findings are consistent with the literature. The findings shed light on several policy implications.

Women own fewer automobiles than men. This could be due to the fact that the increased number of female drivers in our country is a relatively new situation. 
Concerning age factor when categorically taken to see the change in the number of automobiles related to life circuits, it was discovered that young people have less automobile ownership and people over the age of 35 have the highest number of automobiles owned. It is thought that this condition is related to income and getting started in business in an indirect manner.

In terms of marital status, married people have the most automobiles when it comes to marital status. This can be explained by the fact that married people require more automobiles to meet their household needs than single people, and the presence of working spouses or children can sometimes necessitate the need for more than one automobile. In line with this notion, it was discovered that as household size increases, so does the number of automobiles owned by households.

All of the economic indicators have produced results that are consistent with one another. As a natural result of this situation, households with good economic indicators own more automobiles. Those who work have more automobiles than those who do not work, those with a middle-high income have more automobiles than those with a low income, and those a second home have more automobiles.

In terms of social indicators, those who have the habit of eating out have more automobiles than those who don't. Those who have the habit of going to the movies have more automobiles than those who don't. Those who have the habit of going to the market have more automobiles than those who don't. In addition to expressing the sociocultural structure, these variables are also indicators of the welfare level, so parallel outputs with the income level variable are expected.

Those who have difficult access to public transportation have more automobiles than those who have easy access. Those who have difficult access to compulsory education services own more automobiles than those who have easy access. The household's transportation difficulties must have compelled the household to provide more than one vehicle.

The increase in the number of automobiles owned by households over the years can be attributed to the family structure, which has grown and diversified over time, and in this case, more than one vehicle will be required.

Examining automobile ownership, in a country like Turkey, whose per capita income is much less from developed countries, will help us obtain valuable findings. Therewithal, the Covid 19 pandemic has given rise to people's desire to distance themselves from public places, and this has started to force people to obtain automobiles.. In some cases, the inadequacy of public transportation, poor transportation comfort, and even the inability to provide transportation without specialized equipment forces people to own an automobile. In addition to 
all of these negative situations, I believe that the study will be valuable in terms of providing the opportunity to evaluate the behaviour of partially high-income groups, in terms of automobile ownership, and will provide beneficial outcomes for the relevant stakeholders.

\section{References}

Alkan, Ö., \& Abar, H. (2020). Determination of factors influencing tobacco consumption in Turkey using categorical data analyses1. Archives of Environmental \& Occupational Health, 75(1), 27-35. https://doi. org/10.1080/19338244.2018.1556200

Alkan, Ö., Abar, H., \& Karaaslan, A. (2015). Evaluation of determinants on number of various information equipment at households in Turkey. International Journal of Business, Humanities and Technology, 5(5), 24-32.

Akay, E. Ç., \& Tümsel, B. (2015). Hanehalkı otomobil sahipliğinin incelenmesi: Ardışık logit modeli. Sosyal Bilimler Araştırma Dergisi, 4(4), 35-45.

Çınar, M . (2018). Çalışan Bireylerin Otomobil Sahipliğini Etkileyen Faktörler: Bursa Örneği. Yalova Sosyal Bilimler Dergisi, 8(16), 1-19 .

Dinarcan, G. N. (2018). Sayma verisi için regresyon modelleri ve bir uygulama, Ankara, TR: Hacettepe University.

Gómez-Gélvez, J. A., \& Obando, C. (2013). Modeling car ownership in urban areas of developing countries: case study of Bogotá, Colombia. Transportation Research Record, 2394(1), 111-118.

Guo, Z. (2013). Does residential parking supply affect household car ownership? The case of New York City. Journal of Transport Geography, 26, 18-28.

Karaatlı, M., Helvacioğlu, Ö. C., Ömürbek, N., \& Tokgöz, G. (2012). Yapay Sinir Ağlari Yöntemi ile Otomobil Satiş Tahmini. Uluslararası Yönetim İktisat ve İşletme Dergisi, 8(17), 87-100.

Li, J., Walker, J. L., Srinivasan, S., \& Anderson, W. P. (2010). Modeling private car ownership in China: Investigation of urban form impact across megacities. Transportation research record, 2193(1), 76-84.

Memişoğlu, O., \& Can, A. K. (2021). Lüks Otomotiv Sektöründe Satın Alma Kararını Etkileyen Faktörler. R\&S-Research Studies Anatolia Journal, 4(1), 1-12.

Oakil, A. T. M., Manting, D., \& Nijland, H. (2016). Determinants of car ownership among young households in the Netherlands: The role of urbanisation and demographic and economic characteristics. Journal of transport geography, 51, 229-235.

Otken, B., \& Gümüşay, M. Ü. (2009). Karayolunda Hareket Halindeki Taşıtların Çevreye Yaydıkları Emisyonların Analizi İçin CBS'de Arayüzlerin Hazırlanması. Jeodezi ve Jeoinformasyon Dergisi, (101).

Potoglou, D., \& Kanaroglou, P. S. (2008). Modelling car ownership in urban areas: a case study of Hamilton, Canada. Journal of Transport Geography, 16(1), 42-54.

Ritter, N., \& Vance, C. (2013). Do fewer people mean fewer cars? Population decline and car ownership in Germany. Transportation Research Part A: Policy and Practice, 50, 74-85. 
Scott, D. M., \& Axhausen, K. W. (2006). Household mobility tool ownership: modeling interactions between cars and season tickets. Transportation, 33(4), 311-328.

TUIK. Hanehalkı Budget Survey. Retrieved 10.3.2021 from https://www.tuik.gov.tr/Kurumsal/Mikro_Veri

Üçdoğruk Birecikli, Ş., \& Şengül, S. (2021). Uygulamalarla Mikroekonometri. Ankara: Nobel Akademik Press. 